\title{
Rethinking sin and evil through the life of a child sex slave
}

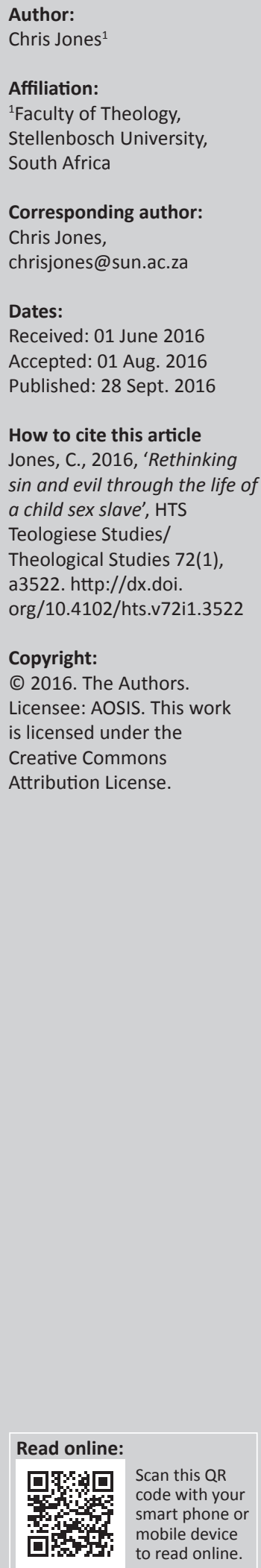

\begin{abstract}
This article rethinks (original) sin and evil through the life of a child called Engela who has been 'sold' into sex slavery. Focus is placed on the high value with which children should be regarded, especially children who have been sold as sex slaves. During this argument the emphasis is placed on ecclesiastical evolutionary perspectives on creation as well as relevant and contemporary understandings of sin and evil, and related to this, the devil and hell. Towards the end of the article theological consideration is given to fatherlessness, because Engela's father was often absent in her life. According to literature, Jesus in all probability grew up without a father too. It seems as if Joseph played a minimal role in his life and education, whilst Jesus' own experience of rejection laid the foundation for his compassion with the socially rejected, particularly children. Fatherlessness from a black African liberation perspective is also contextualised and applied.
\end{abstract}

\section{Introduction}

This article rethinks sin and evil through the life of a child who has been 'sold' into sex slavery. It is done by focussing on the high value of childhood; the meaning of our baptism; the child in our midst and creation. Contemporary views of sin and evil as well as ecclesiastical evolutionary perspectives on the doctrine of sin will be addressed. Related to sin and evil, it also rethinks the existence of the devil as a person and an eternal hell where people will be punished who die without God, according to traditional understandings of church confessions and doctrine. It also shows how Christ in all probability grew up without a father in Galilee. It seems as if Joseph played a minimal role in his life and education. Jesus's own experience of rejection laid the foundation for his compassionate service to the socially rejected, particularly children. He wanted to guide them in a non-judgemental way to the higher reality of the loving community of God. He wanted to show them, especially us adults, the way to the final harmonious unity with God, as he did with Engela, a rejected and largely fatherless girl from South Africa who was 'sold' into sex slavery. Fatherlessness in Africa is also applied and contextualised from a black liberation point of view. Many children in South(ern) Africa grow up without a father and without a paternal rolemodel, become exceedingly vulnerable, exposed and labelled.

'Engela' is a pseudonym. The real name of this child is Elanie Kruger, but in the popular book written about her life (see below) she is referred to as 'Engela'. Permission has been obtained from all relevant parties to retell her life story published in the book called: Van Skoolbank tot Bordeelbed (which means: from school desk to brothel bed).

\section{Research methodology}

The author has, in his research in this regard, spoken to and read about numerous young women who had been caught up in child sex slavery (and prostitution). Of these, the story of Engela is probably the most powerful illustration of the presence of sin and evil specifically in the life of a child who has been 'sold' into sex slavery. The life story of Engela begs us to listen very seriously and with respect, dignity, discernment and recognition to individual's experiences. This is the only possible way to contribute to people's healing, to change their personal, social and religious environment and the only way to address the sometimes judgemental doctrine and devaluating practices of certain religious people.

The life story of Engela has been chosen to serve as a window through which a broader social reality, in this case child sex slavery, can be viewed and understood. The aim is that it may help us to become more aware of injustices and harm done to people when they, in the context in which they live or into which they have been forced, find that they cannot exist as authentic people. Coupled with this, one of the most valuable aspects of this narrative is that it awakens (though 
often indirectly) some critical questions about traditional understandings of sin, evil, the devil and hell. It can also academically be brought into meaningful conversation with scholarship not only about God, Jesus and fatherlessness but also with the African and black theological discourse regarding fatherlessness.

The narrative itself may seem lengthy and by condensing it one will surely get to the (systematic) theological arguments sooner, but in the process it might take away the power and meaning carried by the narrative itself. The narrative has therefore not been cut, in order to retain its power and meaning.

\section{Theological lens}

This article deals with biblical material in a manner which is foreign to the traditional, reformed interpretation of Scripture. For the author the Bible is not the Word of God which, after intensive study, offers theological certainty and godly answers to all our theological questions. The Bible is regarded as a human book, and our interpretation of it considered subjective.

The author has stepped away from the grip of the original fall and has abandoned the idea that human beings should be blamed for all the evil in the world. The author has also given up on the idea of the Augustinian paradigm of theology in order to make the teachings of sin and evil among others more relevant and meaningful to postmodern people (see arguments below).

\section{The life story of a child sex slave ${ }^{1}$}

Since she was a small girl in Brits, Gauteng, South Africa, she was acutely aware of the poverty, hunger and parental conflict in their home as these three things were always part of her life. Food on the table was scarce and the sheriff of the court was fond of their doorbell. Money was a rare commodity and this caused her father, Andries, and mother, Dorothy, to resort to alcohol abuse. Her mother moved from their house in Bloemfontein to a flat in the city centre and Engela stayed behind with her father. A new man, Joshua, then entered her mother's life - someone who could care for them. A year later she moved with her mother and Joshua to Dewetsdorp. Here, however, the household fighting between her mother and her new boyfriend, compounded by the abuse of alcohol were no better than before. Everyone in Dewetsdorp knew Engela's stepfather as the man who liked to drink and could pull out a revolver if not appeased.

Through all of this Engela was miserable and then her mother died. After that her biological father and his new wife moved to Dewetsdorp to care for Engela, so it was not necessary for her to change schools again.

Engela's personal life was ridden with secrets by this time. She was marginalised at school, but a man named Marius took her

1.Based on the book by Hough-Coetzee with Elanie Kruger (2015:9-176), with the permission of the publisher and the persons about whom the story is told (as indicated in the text). under his wing. He told her not to worry about being teased and helped her to become part of Group 13. This Satanist group made her feel 'invincible'. Nobody else wanted to be her friend, but she felt that Group 13 understood her.

She started to play truant, to drink heavily and to listen to 'heavy metal' music. Members of the group burnt each other with cigarettes; tore pages out of the Bible, wrote graffiti saying that Satan was the victor and etched satanic symbols onto their school bags and into their books.

As a child she swore she would never drink, because she saw how it destroyed her family. As a teenager however, she started drinking too, besides smoking and using offensive language. She did however, break away from Group 13. One day Engela was sitting under a tree, smoking (she had a special connection with trees, since her mother used to tie her to a tree when entertaining male friends in the house when Engela was small), when she heard a vehicle in the street. It was Marius, who gestured across his throat that Group 13 was going to kill her and she was terrified. When she found a dead cat tied to their garden gate, she decided to flee. Engela hitchhiked to her brother and his wife in Bloemfontein, she looked for a job for 3 weeks, with a one-page CV but had no luck. She was 16 years old.

Early one morning Engela's brother stood at her bedroom door. Her mouth still tasted of the previous night's red wine. Her head ached. He told her his friend Pieter had a job for her. She had to pack her bags and he would take her there that night. That night they stopped at a place called La Femmé. A big red arrow flickered ENTRANCE. Inside Engela was drugged and sexually abused.

When Engela was in Grade 5 her brother forced her to go with him to his Maths teacher's farm, where the teacher took her to the stables, abused her and then gave her food and presents. Her brother did all sorts of mechanical jobs on $\mathrm{Mr}$ de Wet's farm. Afterwards he always let Engela have a bath. She always wondered if she was smelly. She didn't bath regularly at home and seldom had soap.

When Engela woke up in La Femme, it was dark in the room where she lay. Her head was spinning and she ached all over. Her body was shaking from the cold. Her lower body was so sore she could not sit up. She fell back on the bed. She had no idea what had happened or where she was. Her legs felt lame and sticky, covered in dry blood and she was naked. She felt as sore as the day, six months before, with the teacher in the stables. It felt as if her lower body had been torn apart. She screamed for help, but there was nobody in the building. It was only when the warm water soaked her bruised body that she started crying. She knelt down in the corner of the shower. The water washed away the remnants of the gang rape from her body. Blood and tears mingled, then disappeared down the drain.

In Sunday school she was taught the blood of Jesus washes away your sins like water, until you were clean. She poured a 
large dollop of body soap into her hand and scrubbed her body. The distraught girl wanted to wash the bruises, the previous night, the teacher and Group 13 from her body. She continued scrubbing and scrubbing. Engela's Sunday school teacher had said, once you had been washed clean, you were a new person. She looked into the mirror, but the same old girl looked back at her. In this unfamiliar room she was attacked by images of her past. Bread knives, pistols, screams, blood, Satanism, before she fell asleep. When Engela awoke, sweaty and confused, she heard the locks open and then two girls started coaxing her to get up and get ready for the evening. The girls, Jacky and Nadia, were going to look after her and get her ready for work as a sex-worker under the name of 'Sammy-Jo'. She was given alcohol and a tranquiliser and attractive new clothes to wear.

The next morning, she woke up in a double bed. She went to the bar for headache tablets, but when she pulled on the door (the entrance gate), it was locked. She got back into bed and wrote in her diary how she'd been taught the night before how to become a sex worker; how she had to watch what the other two women were doing. From room to room. It was a nightmare which would not end. She felt nothing, no pain, no fear. She was too shocked to cry. She couldn't even talk. She was completely numb. Then she started praying, for the first time in three years. She begged for a miracle; that she would touch the front door and it would open. She begged the Lord because she believed it would happen. Minutes later she got up and walked to the door. She tried to open it, but it remained locked. Furiously she tugged at the door. 'God! You do not exist! You do not exist!' she screamed. 'I begged you, I pleaded with you, but you are not helping me! Where are you when I need you? Where are you? Why won't you open the door for me? Marius of Group 13 was right all along. You do not exist. It is your fault that I am where I am. It is all your fault'.

The tablet she had taken earlier was starting to work. The pain and fury disappeared. She was drifting on a cloud, in a different dimension. To a place where there was no pain, anger or memory. Sometime later that day two of the club bosses came to her room. They wanted her to get up. She jumped out of bed and hit one of them on the chest, crying and screaming that she did not want to be there. They undressed her, pinned her down and took turns raping her. Now at least she knew how it was done. The next night she would have to satisfy her first three clients. But that afternoon, before her first session, her employers told her in their office that they would forgive her transgressions if she played her part. She stared at the carpet in the office, at the same patterns Pieter (Engela's brother's friend) had stared three months earlier when one of the owners gave him an ultimatum about his outstanding debts.

'Bring us a girl', one of the owners had threatened. 'Bring us some fresh blood, otherwise you will drown in your own blood'. Two months later Engela entered the workshop with her brother looking for a job. Engela agreed to what the owners demanded. By eight o' clock the first clients arrived and Sammy-Jo performed as she had been taught. In her workroom, though, she told her client she did not want to be there and asked him to phone the police. Unexpectedly, she started crying. He pulled on his clothes and went to tell the owners what had happened. After she had gone back to her bedroom and cried, one of the owners went in, furious, and beat and slapped her.

Jacques, a young student who did the books for the club for extra income, was the one to help her after he had come upon her in her bedroom. The two women also came to her rescue. They calmed her down with strong alcohol and pills, which had become part of her daily routine. Later Jacques told her his story. How his father had died in a farm attack and he largely had to fund his studies himself. While working at a hotel bar he had met one of the club's bosses who persuaded him to come work for them.

Sammy-Jo lived locked up like a prisoner. She pushed notes with the word 'HELP' underneath the front door, but nobody responded. While stumbling to her room she'd whisper: 'God, help me'. When Engela fell asleep, she revisited her broken past in her dreams. She dreamt of the policeman who brought her the letter - found at the scene of her mother's suicide. It was for her, Engela. She opened it. 'My darling Engela, I am sorry about doing this. Mommy loves you very much, but my migraines are driving me crazy. I cannot go on like this. Mommy loves you very much'.

Engela and Jacques, the student who did the club's books had become good friends and started sharing their life stories with each other. He once took her to a hotel where a client had booked her and begged her not to try to escape, because he knew the owners would find her again. A few months after really getting to know Jacques he did not return after a holiday. It was said that he had been in an accident - now Engela's hopes of escaping were dashed and she was deeply upset.

She met Ian at the club; a somewhat quiet new client. Afterwards he booked her for the next night in his hotel room. He demanded that she tie her hair in a ponytail and bring along a teddy bear. The owners burst out laughing. One of the owners, Steve Grand, personally took Sammy-Jo to the hotel the next evening. There were many holidaymakers in the entrance of the grand hotel. She was taken to the room. While Steve had a drink a waiter started telling him an elaborate story. Finally, he told Steve there was a phone call for him, but it was just a scheme to distract him. He asked to phone Ian from the front desk, but was told that the room had not been booked. When he did manage to visit the room, only a coat and the teddy bear were in the room: Engela had escaped with Ian.

A card was hanging from the rear view mirror in Ian's car: Nothing is impossible with God. Ian and Engela talked about the rescue effort. Engela had to wear a ponytail so no hair would show under the wig. All the money she had earned was hidden inside the teddy bear. The police conducted a successful raid on La Femmé the same night. 
Engela got off in an eastern Free State town. The card was still hanging on the rear view mirror: Nothing is impossible with God. Someone was walking towards them in the dark. Engela could not see his face, but the figure looked familiar. 'Hello, Engela', Jacques said. 'I am glad you are finally safe. Really glad!' (Hough-Coetzee 2015:9-176).

\section{Engela's journey from there}

It took a long time before Engela could start functioning normally after that. Emotionally she was like a robot, but with time she was freed from drugs and alcohol. She never saw her stepfather again. Her father and brother died. She could never talk to her brother about everything. She did, however, discover that God loved her as well as her daughter who had been born in the meanwhile. For her God is real and he is the one who can help one make the right choices. She tells how she will never forget these words of Christ: 'Let the little children come to me, and do not hinder them, for the kingdom of heaven belongs to such as these' (Mt. 19:14).

One cannot always choose what happens to you, but you can choose how you handle these things that happen to you, she says. And forgiveness, for yourself too, is incredibly important. Her work as a teen sex slave broke her as a person. But over the years the mercy, love and goodness of God (and people), who had always been present in her life, largely healed her (Hough-Coetzee 2015:180-202).

\section{Shocking statistics and practices}

There is a difference between prostitution and human trafficking. Prostitutes normally decide for themselves to earn a living from sex work. They are usually not forced by anyone and they can choose when to do this work. Human trafficking is different. Parents (in South Africa) sell their children as sex slaves to syndicates for as little as R250.00 (Hough-Coetzee 2015:185). In this industry innocent children and teens are kidnapped, held prisoner, drugged and forced to have sex with clients. They are sold against their will into the sex trade. Child trafficking victims, come from all backgrounds, including both boys and girls. They span a wide range from 1 year to 18 years old. Sex trafficking victims up to roughly 25 years old most often started as young as 14 years.

Brothel owners are forever looking for new 'blood'. The victims are sold within months from one brothel to another. While they are drugged, they are raped and photos are taken of them, which are used to blackmail them later. Their clothes and shoes are taken away, so that they cannot escape. Some of these girls do not even have breasts yet. In some cases, they are taken to clubs and brothels where they are kept drugged, beaten and abused. They are kept prisoner and are constantly watched. Some girls are even sold from person to person - this problem is larger than we realise.

Trafficking is done by both local and foreign perpetrators. One of the biggest contributing factors to trafficking is that there is too much free access to our borders. We need more border control and national government must make sure we get our specialised units back. Another danger is when these perpetrators are arrested but not convicted, they come back and search for these girls because they now have their details. The scars never heal for these children; many are so damaged that they go back to the streets and prostitute themselves (Sylvester 2012:n.p.).

When the bodies of these victims are so damaged that they are no longer of any use, they are disposed of. Many of these victims are never found again. No trace or body is left behind. According to Hosken (2013):

South Africa ranks among the 10 countries in Africa where human trafficking is worst, with 100000 people reportedly being trafficked in the country annually. And experts believe this number is not a true reflection of the crime as legislative shortcomings hinder prosecutions. (n.p.)

Dr Monique Emser, of the KwaZulu-Natal Human Trafficking, Prostitution, Pornography and Brothel Task Team, is of the opinion that 'South Africa is an extremely exploitative society, with poor attitudes regarding women and children. [There is] a low value of life that leads to people being viewed as commodities' (Hosken 2013:n.p.).

Although the proclamation of anti-trafficking legislation has hugely improved, South Africa still lags far behind other countries (Hosken 2013:n.p.). Sylvester (2012) states:

South Africa is a hotbed for the billion-dollar human trafficking industry ... The Centre for International Policy's Global Financial Integrity programme estimated that during 2011 global human trafficking accounted for R230 millions of illicit trade, only one third behind drugs and counterfeit goods. (n.p.)

According to Joan van Niekerk from Child-line, South Africa, human trade 'is a significant problem in South and Southern Africa and is fed by our high levels of poverty, orphan-hood and parental irresponsibility' (Sylvester 2012:n.p.). Barbara Ras, founder of the Atlantis Women's Movement and a shelter for trafficked victims in Atlantis, is of the opinion that ' $[\mathrm{t}$ ]raffickers are unscrupulous people and they must be brought to book. And if people know about it, they must speak out' (Sylvester 2012:n.p.).

\section{Highly valued childhood}

Engela realised that, although she rejected God in her youth, God was the one who was present throughout her life and the one who carried her through each crisis. God values each of us and looks after all of us - children, as well as adults. We are created in his image. According to Psalm 8 God created us a little lower than the heavenly beings and crowned us with glory and honour.

Engela came to the conviction that we must always hold onto God and give unto him all our pain and worries - we do not have to carry these burdens ourselves. God may seem absent in some situations, but, in hindsight, when one can see the bigger picture, one realises that God had always been there. 
Engela made Psalm 139 her own: 'For you created my inmost being; you knit me together in my mother's womb. I praise you because I am fearfully and wonderfully made; your works are wonderful; I know that full well'. This highlights the special value which God awards each of us during creation - as told by David - and is here developed and further reasoned.

\section{An alternative meaning of our baptism}

To the author baptism reminds one of the values that meant so much to Engela - that we belong to God; that God made us. It reminds us that God carries, holds and nurtures us every day, until the day that we die, with the same 'hands' with which we were formed in our mother's womb - or, according to Isaiah 46:3-4 'you whom I have upheld since you were conceived, and have carried since your birth. Even to your old age and grey hairs'.

With nurturing hands, God ignites a flame of love and goodness in us at birth, a flame that can never be extinguished. In a sense, this is what it means to be formed in God's image: deep inside us burns a flame of God's love, goodness and holiness. This flame of love and goodness is not only fed and nurtured daily by God, but this flame, this core of goodness and love which each of us carries as a result of being born in the image of God, is indeed more fundamental and crucial in our lives than all the evil we are exposed to- it lies deeper. Of course it is not always easy to see or believe it - especially when we are confronted, and sometimes overwhelmed, by our own hardships, mistakes, sins and the evil of the world. Belief that there is a flame of God's goodness burning inside of us, that God nurtures it, is sometimes only visible in the fever, the yearnings for it that stir deep inside us, just like in Engela's life when she called upon God in her difficult circumstances.

But this is often enough. This is often all that is needed. Romans 8:26-27 tells us that in our weakness the Spirit helps us and 'intercedes for us with groans that words cannot express', a yearning for something better; for his care, his mercy, which often, when we patiently wait for it, comes into our lives in unexpected ways, through the kindness of people, the beauty of nature and the touch of a stranger. And we again realise that we are held by God, despite ourselves; we are baptised.

Engela later writes that she knows her parents, in their own way, did their best for her and her brother. Despite all the swearing, poverty and violence she did not see her mother as a bad person. She remembers her big beautiful brown eyes, her broad smile and her gentleness, which sometimes shone through. She remembers the wonderful times when her mother was sober, how she hugged Engela and told her how much she loved her. This beautiful image could have been so much better if alcohol had not consumed their lives. But without it they could not have survived their daily agony.
For Engela, a flame of goodness and love shone through her parents, a flame which not even alcoholism, swearing, poverty and violence could douse. And this is critically important. We are all created beings by God in God's image and therefore we carry the flame of love and goodness in us. This flame is not only fed and nurtured daily by God, but this flame, this core of goodness and love, is indeed stronger than the evil in the world. We are called upon and challenged to keep this flame burning in other people's lives. In this way we become co-creators with God.

Today Engela understands something of this because she reaches out to other (former) sex victims and encourages them to unburden themselves so that they can be healed. She talks to them about the power of forgiveness and acceptance and gives essential practical tips to parents and children. The saying 'your test will become your testimony and your mess will become your message' is indeed true for her.

An important perspective out of the early church regarding the high value placed on children and their christening comes from John Wall's (2006) review of O M Bakke's book, When Children Became People. The Birth of Childhood in Early Christianity. It appears according to Wall's reading of Bakke that early church fathers such as Clement, Origin and Tertullian exempted early childhood from sinfulness as primarily a time of 'innocence' including simplicity, sexual purity, lack of desire, and indifference towards status and wealth. Wall (2006) states:

Cyprian and Gregory depict infants as coming into the world as complete human beings, as fresh creations of God, and hence without sin. Chrysostom argues that as images of God children may easily be formed by their parents as an artist forms a sculpture.

All of this changes, however with Augustine. Augustine famously insists in Confessions and other writings that children enter the world as lacking innocence because they are already bound up in Adam's original sin.

Why this rather dramatic shift? Bakke's argument is that Augustine uses childhood as the prime exhibit in his opposition to Pelagianism. Infant's inborn corruption by desire and guilt proves Augustine's larger theological point that humanity is absolutely fallen from God and therefore in need of God's grace. (pp. 338-339)

What Bakke does not note in this regard, according to Wall (2006:339-440), is the fact that Augustine is drawing here in part on the considerably more negative assessments of childhood from Plato. Viewing children as 'innocent' and without sin, however, invests them with much greater humanity.

\section{The child in our midst}

For the Christian community it is important to embrace children like Engela. We may not personally know such children, but there are possibly people among us who have been directly affected by such experiences. However, one realises that such children, and especially their parents, do not 
live like God expects us to live, but we dare not judge such people. The flame of God's mercy, goodness and love still burns in their lives, although not to the extent God intended.

We dare not view sin solely from the perspective of its monstrous power but rather from the conviction that Christ's healing mercy is a stronger force. According to the prophet Isaiah, a servant of God will not break a bruised reed or snuff out a smouldering wick (Is. 42:3). Forgiveness of sin is important and essential. When this happens, this flame in our lives burns more strongly and enables us to help others to also let their flames shine out.

For this we, like Engela, must acknowledge our share of sin. We must analyse it. We must call it by its name. We must accept responsibility. And '[R]esponsibility does not climax in guilt but grows in gratitude, trust and hope' (Willmer 2007:20-21). You have to confess and you have to show remorse. You must be able to forgive others as well as yourself. Without forgiveness you cannot truly be free. When you forgive, restitution can take place, leading to complete freedom, allowing you to live to your full potential, according to the truth, and be healed.

\section{Sin, evil and creation - a few important contemporary views}

The Stellenbosch philosopher and ethicist Anton Van Niekerk (2005:17) argues that it cannot really be expected of modern people to believe that the earth is 6000 years old; or that Adam and Eve are the parents of all humanity, who lived in a perfect paradise as a species that represents modern humans before committing a transgression with catastrophic results, not only for them, but for all humans and creation. This of course leads to the rejection of the church's confession of the doctrine of sin especially the so-called original or ancestral sin of which Augustine was an important exponent. The rejection of the idea that Adam and Eve were historical people, of course, draws a line through the idea that what has been done by them, would have a permanent, disastrous result for all members of the human race.

'You can't truly believe that God holds billions of generations, also while they are still infants, accountable and punishable for the sins of the "first people", argues Van Niekerk (2005:17). Should all of humanity be condemned to this fate? What about those who never had the opportunity to convert to Christianity, who never heard the Christian message, the message that they would be lost, that they are condemned to eternity? Can one really take such a God seriously? According to Van Niekerk (2005:18), Charles Freeman (2002) says that traditional teachings such as those on original sin cannot be interpreted outside of their social, cultural and historical backgrounds. These teachings date from a time when sexuality was judged exceptionally negatively.

Influential figures such as Tertullian, Jerome and Ambrose had a powerful effect on these developments. Tertullian wrote that marriage and prostitution only differ because of the law; they are actually not that different and only vary according to the level of illegitimacy (Van Niekerk 2005:18).

The church father Augustine (Van Niekerk 2005:18) argued that original sin was literally passed on from generation to generation through sex. Freeman (2002:299), in his book, quotes the following passage from the work of Julian of Eclanum (386-455), who was banned because of his support for Pelagius's dispute with Augustine over original sin:

Babies, you say, carry the burden of another's sin, not any of their own ... Explain to me, then, who this person is who sends the innocent to punishment. You answer, God ... God, you say, the very one who commends his love to us, who has loved us and not spared his son but handed him over to us, he judges us in this way; he persecutes new born children; he hands over babies to eternal flames because of their bad wills, when he knows that they have not so much formed a will, good or bad ... It would show a just and reasonable sense of propriety to treat you as beneath argument: you have come so far from religious feeling, from civilised standards, so far indeed from common sense, that you think your Lord capable of committing kinds of crime which are hardly found among barbarian tribes. (pp. 386-455)

You cannot but agree with Julian. How can you reconcile the God of the Bible, the God of love and goodness, with this interpretation of original sin? Is this how God would have looked at Engela? Is this how he would have judged her? Would God have delivered her to the flames of eternity should she have died as a sex slave? Does the love and goodness of God not force us to offer alternative interpretations of sin, its origin and functioning, especially now, when certain traditional answers are (no longer) meaningful and satisfactory for the postmodern human due to new scientific discoveries?

This approach does not mean that one should discard one's faith or renounce one's beliefs. Loss of faith is not the price we pay for modernity, according to Van Niekerk (2005:23). Instead, we are asked to believe differently, rather than be constricted by literal interpretations of what is written in the Bible and blindly and uncritically accepting and following the teachings of church tradition and confessions. Reformation means continuous change. In fact, a number of contemporary theologians also renounce the notion of original or ancestral sin, among others the consummate South African Old Testament scholar Sakkie Spangenberg (2010). In his article The crumbling of the Augustinian paradigm of theology? A critical discussion of Cornelis Blom's book Zonder grond onder voeten (without any foundation), he confirms certain aspects of Blom's reasoning, but also raises a few questions concerning his approach, analysis and conclusions. According to Spangenberg (2010:n.p.), Blom (2009), in his focus on evil in creation asks the question whether God or humans are responsible for sin. Spangenberg argues that (after reading Genesis 1-3) Christian theologians used to come to the conclusion that humans are responsible for evil in the world. Blom comes to a totally different conclusion. According to his reading and understanding of the book of 
Job and Genesis 1-4, there was no fall from a perfect world. Evil existed right from the beginning. Humans were mortal right from the start, and did not become mortal due to a fall. Man was made from the dust of the ground, but this according to Blom indicates human humility, fragility, vulnerability and mortality (Blom 2009:232). However, Blom doesn't spell out what the consequences are for the traditional Christian faith if one gives up the idea of original sin. In this regard Spangenberg (2010:n.p.) ponders the following questions: How do we deal with the Heidelberg Catechism (Sunday 5 \& 6) which suggests that Jesus was untouched by original sin? How should we think about Jesus' humanity? Is it still necessary to insist that he was born from a virgin? Was Jesus not fully human as we are? How does this affect Western Christianity's teaching on salvation and on the final judgement?

For Spangenberg (2010:n.p.) Blom's teaching is not surprisingly new. What is new is the way he goes about arriving at his conclusion. According to Spangenberg (2007:259-279) several Old Testament scholars (whom he doesn't refer to specifically) have already pointed out that the traditional interpretation of Genesis $1-3$ is not valid. Even systematic and practical theologians are beginning to recognize this. Take as an example Dingemans (2000:350), who writes: $E r$ is in de bijbel geen sprake van 'erfzonde!' (The Bible does not mention original sin). Blom (in Spangenberg 2010:n.p.) is looking for good reasons to bid farewell to the idea of an original fall. He searches in the Bible for this foundation and finds it. The book of Job gives him a key to interpret Genesis 1-4. The way he works with these texts, bears testimony of some incisive study, but there are also problems associated with his approach.

The problems can be traced back according to Spangenberg, to the way he uses Scripture as a starting point. According to Blom the Bible is the Word of God, and it is on this basis that we can have theological certainty. Furthermore, he works with a 'correspondence theory of truth'. This means that the text gives us direct access to reality. That is why he makes so much of Genesis 1:2, which according to him, describes the world before creation.

Finally in his analysis of the relevant chapters he makes use of narrative analysis. However, this kind of relationship with the biblical material does not correspond satisfactorily with the traditional interpretation of the Scripture. For example, he does not distinguish between the different God characters in the stories, but pretends as if all of them describe the same God - the Father, the Creator God of the Christian faith.

Spangenberg (2010:n.p.) refers to Barr (1973:142) who says that the Bible is not the Word of God which, after intensive study, offers answers to our theological questions. The Bible is completely a human book, and we who interpret it, remain trapped in our subjective interpretations thereof. Spangenberg (2010:n.p.) also quotes Philip Kennedy (2006:255) who argues that we cannot make any objective judgements about God.
He also refers to the following words of Kennedy: 'As Christianity begins its twenty-first century, its Augustinian paradigm of theology has met the fate of the Berlin Wall' (2006:252). With the term 'Augustinian paradigm' he summarises the core of Western theology since Augustine (354-430) with the words: Fall-redemption - final judgement.

Blom (in Spangenberg 2010:n.p.) tries to get away from the grip of the fall by giving up the idea that humans should bear blame for all the evil in the world. However, he does not totally give up on the Augustinian paradigm of theology, but remains partial to it. This is evident from his acceptance that Genesis 1-4 and the Book of Job deal with the same God: the Father-Creator God of the Christian tradition, while it is not the case. He does not take into account the development of the Israelite religion. This religion only became monotheistic during the Babylonian exile. Noort (1984:121-136) reasons that such a view of God makes God responsible for both good and evil. The devil character (or Satan) has been introduced in Judaism and Christianity precisely to try and escape from this problem. This Augustinian paradigm of fall - redemption - final judgement has manifested right through the centuries up to today in the doctrines of churches. This well-known paradigm also manifested in the Calvinism of the Canons of Dordt (Van Wyk 2015:n.p.), onto which many contemporary churches still hold.

Everyone sins and is evil, including Engela, her parents and the people who sold and used her as a sex slave. We are all sinners because of the things we do wrong every day, not because we carry the sins of 'our forefathers' that have been passed on from generation to generation by means of sex.

If we cling to the mercy, the goodness of God, it will bring us to experience God's love, the basis of our hope and faith, more and more.

\section{Ecclesiastical evolutionary perspectives on the doctrine of $\sin$}

In the light of the abovementioned perspectives, it is clear to many people that there could not have been a fall from a perfect existence because of the sinful actions of the human race, which therefore rendered every person incapable of doing good. While a personalist interpretation of $\sin$ (as caused by the 'original people' Adam and Eve) informed Protestant belief for centuries, the Roman Catholic Church's theologians developed an evolutionist model along the lines of Teilhard de Chardin's thinking (1968). With this they attempted to make the teachings of sin more relevant and meaningful to modern people.

As a result, they changed the traditional view on original sin in a profound way. Truth be told, the world view in which the theory of original sin developed in its classic form is the antithesis of this evolutionist model. This classic view on original sin, as we know, is based on a perfect beginning. A paradise. On the other hand, the evolutionist model started small, imperfect and incomplete. 
Teilhard De Chardin, according to the South African systematic theologian Jaap Durand (2013a:325), made the idea of sin and original sin in a sense harmless, by seeing it as the inevitable result of an unfinished process of evolution. Evil is a necessary by-product of this process of evolution because there is always the possibility of the accidental and uncertain. Therefore, mistakes are always a real possibility. Sin is the human, conscious form in which evil is reflected (Durand 2013a:204). Teilhard de Chardin was aware of how difficult it is for many Christians to accept evolution, not as a counterpart of traditional creation beliefs of Christianity, but as a more nuanced pronouncement of it, as offered by science (Durand 2013a:274). Although the early church fathers, as explained above, viewed the child as innocent and without sin, preference is given here to the evolutionary model which starts, as already indicated, as small, imperfect and inadequate. Also in a human's life. The point is that there was no perfect creation from which man fell into sin.

Durand (1978:64-78) argues that the teaching of original sin in the context of an evolutionist doctrine is regarded as the theological articulation of the general law of sin that stems from the incompleteness of a developing humanity.

One of the most consistent interpreters of evolutionist thinking in the Roman Catholic Church is A Hulsbosch (1963). He developed a theology of evolution in line with that of Teilhard De Chardin ${ }^{2}$ (Durand 1978:70) and with this as basis he offers us a re-interpretation of the theory of original sin.

For Hulsbosch (1963:45-53) the real difference between a static view of the creation and an evolutionist world view on creation is that in a static world view, God created in the beginning, while in a dynamic world view of evolution the attention is focused on the end. It is all about how this world completes itself - through cosmic evolution. By constantly developing. In this evolutionist doctrine, sin stems from the fact that human beings want to remain what they are by searching for their own happiness in life and rejecting God's ongoing creation. By refusing God's mercy, love and goodness humans dismiss God's way of completing his creation in the belief that they know a better, faster and surer way. Although the evolutionist doctrine of original sin is predominantly found in Roman Catholic Church circles there are a few Protestant scholars such as Berkhof (1952:7-65) who look for answers in this direction. The evolutionist doctrine to which Berkhof subscribes leads him to link original sin directly to the question of the origin of sin, and not the result of sin as traditionally believed in reformed theology. Berkhof (1952:7-65) argues that original sin is, on the one hand, the expression of a 'lower personal' force which does not force, but encourages, humans to $\sin$. On the other hand, it is a suprapersonal force with far-

2.According to Teilhard De Chardin (1968:44-48) evil in its various forms is an inevitable by-product of evolutionary development. In a sense, it is the price paid fo development, according to Durand (1978:71). Because our world is being shaped and realising itself, it inevitably suffers from the fact that it is not complete, and therefore imperfect. A higher level of being is reached when, through developmenta pressure from numerous individuals, a particular section manages to move across certain threshold into a new level of existence. Teilhard De Chardin argues that God created the world in such a way that it has to realise itself; therefore, it has to find its own way from the disintegration to an eventual harmonious unit. reaching consequences for the sin of a human being. The 'lower personal' stems directly from human beings' animal origin. From nature they inherit their natural aggression and desire for individual and collective self-realisation. For an animal these things are morally neutral, but not for human beings because they have something animals do not: freedom.

Because humans are free they are answerable to God for the way in which they conduct their inherited nature. They cannot escape their inheritance, but they are called upon to subject it to their freedom which is aimed at the love and goodness of God and his fellow human beings. In itself this inheritance is necessary for their existence and is not sinful, yet it tries to pull them away from their responsibilities. Sin originates when they do not rule freely over their inherited nature, but are ruled by it. Sin is therefore not the fall from a higher reality, but the refusal or reluctance to rise to the higher reality of the loving union with God. This results in a second aspect of sin. Humans do not sin on their own, but are born into and grow up in a world and society based on (personal and) collective selfishness.

Sin snowballs and is institutionalised on a suprapersonal level in the anonymous powers of existing codes, taboos and traditions relentlessly prescribed by the state, society and party interests. Individual goodwill can hardly stand up to this. The overwhelming majority actually associates with these powers. And in this way humans are subjected to the suprapersonal powers of sin. From this influence they cannot really escape. Often they do not want to either; they join in freely.

The most comprehensive evaluation of the origin of sin from an evolutionist perspective is that of the British philosopher and theologian John Hick (1966:262-327). He rejects the traditional doctrine on human beings' fall from grace at the beginning of human history. This, he argues, is unacceptable in view of scientific knowledge. Death, disease and danger existed long before man.

He also takes issue with the notion that all of humankind should suffer because of the sin of the first human. Morally he finds this indefensible. He further argues that it is impossible for perfect human beings in a perfect world to slide into a state of $\sin$. That would imply the postulation of a self-creation of sin from nothing.

Humans, however, exist some distance away from God's purpose for them, Hick argues, not because they have fallen from that purpose, but because they have not reached it yet (Hick 1966:71-72). The evolutionist model also helps us to see Engela's life in a better light, to not judge her as so many people would have done. She too carried the flame of God's love and mercy in her. Sometimes it was dim, weak and flickering, but God nurtured it and kept it alive. As already indicated, it was only present in her youth in her yearning, the longing for it which stirred deep inside her - movingly illustrated by memories of her Sunday school days and how she had learnt that Jesus washes one clean, her cry to God in 
her time of need, and her clinging to Jesus' love for children. This yearning, this longing for God as indicated above is mostly enough. Often this is all that is needed. As Paul said, when we do not quite know what to pray, the Holy Spirit steps in with inexpressible sighs ... his Spirit calls through our spirit for something better - calls for his care, his mercy which sometimes, when we wait patiently, comes into our lives through the kindness of people, the beauty of nature and the touch of a stranger. Engela too experienced this. God, through God's mercy, love and goodness got her on his way of growth and fulfilment regarding the purpose he had in store for her.

\section{The devil and hell}

In light of this, what role does the devil play in a person's life? What influence does he have on us? To what extent does he determine the course of one's life? Was it the devil who told Engela what she should do? Was he the one who seduced her in his devious ways? For many postmodern people (Du Toit 2012:129-135) it is becoming more difficult to accept the existence of a personal devil. They can at best accept the idea of a devil and demons as personifications. For many people the devil and demons are mythological names for the sins and evil emanating from the 'lower human', but which also surpass the individual, and which simultaneously juxtapose - in a destructive way - the good and constructive forces in a specific person, in the same social and political group and the same historical context (Durand 1978:83).

Evil exists as a phenomenon and this evil does not only exist in individuals, it also exists collectively as other people are influenced and involved. And so it becomes a power that is greater than the individual. Engela's life bears testimony to that. The real evil is, among others, found in the systems, institutions, organisations, clubs and contexts, which we have ourselves created, and which at some stage become too powerful for ourselves. In the ancient religion, people naïvely believed that the heavens were full of heavenly beings, powers and energies, good and evil, and these powers were forever conflicted, but also that they controlled what happened on earth. For this reason, a large part of the faith of humans consisted of being busy with these beings.

For centuries human naïvety was exploited to such an extent that people would sacrifice their lives for their beliefs, beliefs that were founded on tradition. Many of these beliefs were adopted into the doctrines of the church. This is an important subject - namely how much of our religion actually stems from these beliefs and not from the Bible - which is getting far too little attention.

These naïve people usually point to the influence Satan holds over us. For example, even if his name would appear in the name of a mountain or something else. These people then argue that these names should be changed so that these influences on people in that environment can be broken, allowing them to grow spiritually automatically. When looking at such issues one needs the ability to evaluate and to consider carefully the teachings of the Bible while also taking into account post-modern teachings from scientific evidence.

Some theologians also argue that the Bible provides enough evidence that there is no such thing as an eternal hell where this devil reigns (Durand 2013b). In this regard the Old Testament talks of an underworld which is seen as a pitch black land, a place of deathly quiet. At the time the world was seen as having three levels, with the underworld below the earth. Here nobody could praise God, and the righteous, as well as the unrighteous, could land up there. In other words, there was no distinction between those who believed in God and those who did not - all bodies came to rest there. In contrast, the New Testament says that those who do not believe go to hell, while the faithful receive heavenly bliss. But is this true? The New Testament uses various metaphors for hell, such as fire, a burning oven and the deepest darkness. The word 'hell' however refers to a valley outside of Jerusalem where, in Old Testament times, cult ceremonies took place, including the slaughter and burning of children. Later this valley became the place where Jerusalem's rubbish and bodies of criminals were burnt. This fire was always burning or smouldering because there was constantly something to be burnt. This led people to start referring to it as 'an eternal fire'. This was the dominant Jewish theology at the time when Jesus arrived. He subscribed to this theology. This valley was used as a metaphor or image of the destruction and judgement of the unfaithful.

In the Afrikaans Bible (with which I am familiar - I have not come across this in other Bible translations) Paul only once refers to an 'everlasting damnation' (2 Th. 1:9), which symbolises eternal punishment, but this is an incorrect translation and contradictory to his belief that there is no such thing as eternal punishment. He actually used the term 'everlasting destruction'. In earlier and later doctrines and theologies this image of 'an eternal fire' evolved into 'eternal hell' where God punishes the unfaithful and disbelievers for eternity. In the ideology of the church this smouldering fire in the valley outside Jerusalem became a place of eternal punishment as opposed to eternal life.

Many postmodern people find it difficult to connect the idea of masses of people spending eternity in the most awful agony with a God of love and mercy. Thankfully, God's existence is not dependent on the existence of a personal devil. By the same token God's existence does not offer a personal devil a logical right to exist. According to the Bible, evil, whichever way one looks at it, has always belonged to the created reality, while God has always been seen as eternal (Du Toit 2012:129135). The fear of hell and the devil should be banished from our theology and faith. Our children should not be preached to from a theology of fear, but much rather guided in a positive way to live their lives in the image of God (love, goodness, hope and holiness) and the healing mercy of Christ. They should be guided to accept their sins, to acknowledge and confess their transgressions - but from an evolutionist perspective on sin. God created the world in such a way that it has to realise itself. It started small, imperfect and disintegrated, but it must find its own way to an eventual harmonious unity. 


\section{Theological response to fatherlessness}

The sinful and evil practice of human trafficking is fed by high levels of absent fathers (and mothers), parental irresponsibility, rejection and poverty. Jesus' own experience of rejection and possible fatherlessness laid the foundation for his compassionate service to the socially rejected, particularly children. He wanted to guide them in a nonjudgemental way to the higher reality of the loving community of God, his surrogate Father. He wanted to show them the way to the final harmonious unity with God, as he did with Engela, a rejected and largely fatherless girl in Africa.

The South African New Testament theologian Andries Van Aarde (2001:4-6), confirms that Christ's earthly father was largely absent in Galilee, according to the letters of Paul, the gospel of Mark, Q and the gospel of Thomas. Joseph played a minimal role in his life and education (see Van Aarde 2001:206-234 for further scholarly support of this view). In first-century Galilee such children were marginalised and excluded from the possibility of being named children of God; yet Jesus's followers regarded him as the Child of God. According to Van Aarde (2001:4-6) Jesus called on God to be his surrogate Father. In this way Jesus transformed conventional patriarchal values by his compassion for the fatherless children in the Palestine of his time.

What would this 'fatherlessness' look like specifically in an African context, where the story of Engela and the accompanying research of the author originated? Allan Boesak (2011), a well-known black liberation theologian and activist from this continent, converses with Van Aarde on his perspective of Jesus' fatherlessness in order to contextualise it. The title of this article of his is very intriguing: The divine favour of the unworthy: When the Fatherlessness Son meets the Black Messiah.

According to Boesak's reading of Van Aarde, Jesus is clearly not an 'innocuous wisdom teacher' or mere religious figure, but was born to a single mother who lived and worked in Galilee - 'multilingual, inhabited by pagans and Israelites, many of mixed marriage heritages upon whom the Judeans looked down'. These were impoverished people, who tried to live according to ancestral traditions. Purity laws of the sacred writings were taught to and enforced upon them by visiting Judean priests. Jerusalem authorities came to collect the temple taxes from them. These were peasants who survived on small pieces of land, landless tenant farmers who worked for absentee landlords in the cities, incurring huge debts, whilst some were forced off their land and turned to carpentry. Bandits, outcasts and rebels escaped to the mountains and found shelter in caves: "This is the "Galilee of the Gentiles" where people lived in darkness. Somewhere there, Jesus is to be found ... He was a revolutionary and healer, teacher and helper' (Van Aarde 2001:75).
Boesak (2011) further argues that Van Aarde is correct in situating Jesus as 'fatherless in Galilee' and that the 'darkness' in which Galileans lived was surely not simply 'spiritual', but darkness caused by oppression, exploitation, poverty, powerlessness and exclusion.

The marginalisation of and scandal inflicted upon Jesus because of his suspected illegitimacy, were the focus of the tensions with temple authorities. It was not so much the stance of Jesus regarding the ruling elites and the political consequences as how he lived and what he taught. Van Aarde (2010) concludes:

that Jesus was crucified by the Romans 'after an outburst of emotion at the outer temple square', seemingly completely ignoring the political fact that Jesus was executed by order of the Roman governor and that he was killed by crucifixion, a form of execution that the Romans used to intimidate subject peoples by publicly torturing to death their rebel leaders. It was an effective form of rule by fear through intimidation and terror. (p. 78)

Van Aarde's Jesus of history and of faith, the revolutionary, healer, teacher and helper has long been at the heart of Black Christianity. However, this truth did not come automatically to black people in their encounter with the Christian faith, Boesak (2011) reasons, '[I]t is a truth they had to discover themselves despite the Christianity White people brought'. For, as Vincent Harding (in Boesak 1977) writes, speaking for all conquered, colonised and enslaved people:

We first met this Christ on slave ships. We heard his name sung in praise while we died in our thousands, chained in stinking holds beneath the decks, locked in with terror and disease and sad memories of our families and homes. When we leaped from the decks to be seized by sharks we saw his name carved in the ship's solid sides. When our women were raped in the cabins, they must have noted the great and holy books on the shelves. Our introduction to this Christ was not propitious and the horrors continued on America's soil. (p. 4)

What is striking about Van Aarde's Jesus according to Boesak (2011) is 'not just what is written but also what is left unsaid'. What is startling is that he does not point out the one salient feature about Jesus namely his identification with the oppressed and poor. Jesus' family was so poor that they couldn't bring the prescribed sacrifice at his birth. Instead, they brought the sacrifice of the poor namely two turtledoves instead of the year-old lamb (Lv. 12:6-8; Lk. 2:21-24). Jesus belonged to poor people in Galilee - downtrodden, oppressed and exploited by the ruling classes in Jerusalem and the Roman occupiers (Boesak 1977:43-44). We must always remember that Jesus came expressly to preach good news to the poor, to liberate them from their captivity and to restore their humanity. He identified himself with the poor and with their struggle for liberation. In the Gospels, Jesus becomes the poor, the hungry, the naked, the imprisoned and the sick. In Black theology these are not mere spiritual connotations, but the actual conditions of people living with naked brutality and oppression (cf. Boesak 1977:42; Felder 1992:19). For us, the historical Jesus is the embodiment of God's preferential option for the poor. 


\section{Conclusion}

Engela's story challenges us to rethink sin and evil, the consequences thereof as well as how to deal with it in the life of a child sex slave. New ways of thinking have been embarked upon to be considered as possible alternatives to traditional doctrines on how we as humans can actualize ourselves within an evolutionist model of creation, through which the teachings on creation, sin and evil can become more relevant and meaningful for post-modern people. The challenge now is that we will have to reflect critically on these perspectives so that we can guide people like Engela, especially fatherless, rejected children, pastorally and ethically in more constructive and healing ways.

\section{Acknowledgements Competing interests}

The author declares that he has no financial or personal relationships which may have inappropriately influenced him in writing this article.

\section{References}

Barr, J., 1973, The Bible in the modern world, SCM, London.

Berkhof, H., 1952, Christus en de Machten, G.F. Callenbach, Nijkerk.

Blom, C., 2009, Zonder grond onder de voeten: Een theologische analyse van het boek Job en Genesis 1-4 vanuit het perspektief van het kwaad in de schepping [Withou any foundation: A theological analysis of the book of Job and Genesis 1-4 from the perspective of evil in creation], Boekencentrum Academic, Zoetermeer.

Boesak, A.A., 1977, Farewell to innocence: A socio-ethical study on Black Theology and Black Power, Orbis Books, Maryknoll, NY.

Boesak, A.A., 2011, 'The divine favour of the unworthy: When the Fatherless Son meets the Black Messiah', HTS Teologiese Studies/Theological Studies 67(1), Art. \#933, 9 pages. http://dx.doi.org/10.4102/hts.v67i1.933

Dingemans, G.D.J., 2000, De stem van de Roepende: Pneumatheologie [Die stem van die Roepende: Pneumateologie/' $n$ Teologie vanuit die perspektief van die Gees], Kok, Kampen.

Durand, J., 1978, Die Sonde, NG Kerkboekhandel, Pretoria.
Durand, J., 2013a Evolusie, Wetenskap en Geloof.'n Biografiese inleiding tot die denke van Teilhard de Chardin, Lux Verbi BM, Wellington.

Durand, J., 2013b Enkele perspektiewe oor die vraag na die hel; Kerkbode, viewed 21 June 2013, from http://kerkbode.co.za/enkeleperspektiewe-oor-die-vraagna-die-hel

Du Toit, B., 2012, God? Geloof in 'n postmoderne tyd, Griffel, Kaapstad.

Felder, C.H., 1992, Troubling biblical waters: Race, class and family, Orbis Books, Maryknoll, NY

Freeman, C., 2002, The closing of the Western mind. The rise of faith and the fall of reason, William Heinemann, London.

Hick, J., 1966, Evil and the God of love, Palgrave MacMillan, New York.

Hosken, G., 2013, 'SA is a major highway for human trafficking', The Times, viewed 6 November 2013, from http://www.timeslive.co.za/thetimes/2013/11/06/sa-isa-major-highway-for-human-trafficking

Hough-Coetzee, J. \& Kruger, E., 2015, Van Skoolbank tot Bordeelbed. Gebaseer op ' $n$ ware verhaal van geloof en oorwinning, Delta Publishers, Jeppestown.

Hulsbosch, A., 1963, De Schepping Gods, J. Romen, Roermond.

Kennedy, P., 2006, A modern introduction to theology: New questions for old beliefs, I.B. Tauris, London.

Noort, E., 1984, 'JHWH und das Böse: Bemerkungen zu einer Verhältnisbestimmung [JHWH and evil: Comments on the relation]', in A.S. Van der Woude (ed.), Prophets, worship and theodicy: Studies in prophetism, biblical theology and structural and rhetorical analysis and on the place of music in worship, pp. 121-136, Brill, Leiden.

Spangenberg, I.J.J., 2007, 'Can a major religion change? Reading Genesis 1-3 in the twenty-first century', Verbum et Ecclesia 28, 259-279. http://dx.doi.org/10.4102/ ve.v28i1.107

Spangenberg, I.J.J., 2010, 'Die verkrummeling van die Augustiniaanse paradigma in die teologie? ' $n$ Kritiese bespreking van Cornelis Blom se boek Zonder grond onder de voeten', HTS Teologiese Studies/Theological Studies 66(1), Art. \#848, 7 pages. http://dx.doi.org/10.4102/hts.v66i1.848

Sylvester, W., 2012, Shocking reality of SA human trafficking, viewed 31 January 2012, from http://www.iol.co.za/news/crime-courts/shocking-reality-of-sahuman-trafficking-1224202

Teilhard de Chardin, P., 1968, De Menselijke Energie, Het Spectrum, Utrecht.

Van Aarde, A., 2001, Fatherless in Galilee. Jesus as child of God, Trinity Press International, Harrisburg, PA.

Van Niekerk, A.A., 2014, Geloof sonder sekerhede. Hoe glo ons vandag? Lux Verbi, Wellington.

Van Wyk, T., 2015, 'Die Dordtse Leerreëls: 'n Grammatika van geloofstaal gebore uit die nasie-staat-ideologie', HTS Teologiese Studies/Theological Studies 71(3), Art. \#3051, 11 pages. http://dx.doi.org/10.4102/ hts.v71i3.3051

Wall, J., 2006, 'When children became people. The birth of childhood in early Christianity (O.M. Bakke, 2005, Fortress, Minneapolis, MN)', Interpretation 60(3), 338-340. http://dx.doi.org/10.1177/002096430606000314

Willmer, H., 2007, Experimenting together: One way of doing child theology, Child Theology Movement, London. 